\title{
A NOVEL ENVIRONMENTALLY FRIENDLY 2,4,6-TRINITROTOLUENE (TNT) BASED EXPLOSIVE
}

\author{
Gibson S. Nyanhongo ${ }^{1}$, Nina Aichernig ${ }^{1}$, Marcus Ortner $^{1}$, Walter Steiner ${ }^{2}$, Georg M. Guebitz ${ }^{1}$ \\ ${ }^{1}$ Department of Environmental Biotechnology, Graz University of Technology, \\ Petersgasse 12, A-8010, Graz, Austria \\ ${ }^{2}$ Institute of Biotechnology and Bioprocess Engineering,' Graz University of Technology, \\ Petersgasse 12, A-8010, Graz, Austria. \\ g.nyanhongo@tugraz.at
}

\begin{abstract}
A novel bioremediation technology has been developed. This technology involves the incorporation of a newly isolated Pseudomonas putida GG04 and Bacillus sp. SF into an explosive formulation to enhance biodegradation of TNT residues and explosives which fail to detonate due to technical problems. The incorporation of these microorganisms into the explosive did not affect the quality of the explosive in terms of detonation velocity while complete degradation of TNT moieties upon transfer in liquid media was observed after 4 days. The incorporated microorganisms sequentially reduced TNT leading to the formation of hydroxylamnidnitrotoluenes (HADNT), 4-amino-2,6dinitrotoluenes; 2-amino-4,6-dinitrotoluenes, different azoxy compounds; 2,6-diaminonitrotoluenes and 2,4diaminonitrotoluenes. Aminodinitrotoluenes (AMDNT) and diamninonitrotoluenes (DAMNT) constituted the predominant metabolites which steadily increased achieving $41 \mu \mathrm{M}$ and $63 \mu \mathrm{M}$ in P. putida GG04 cultures and, $73 \mu \mathrm{M}$ and $109 \mu \mathrm{M}$ in Bacillus SF cultures, respectively. Although both microorganisms use NAD(P)H dependent enzymes to transform TNT, $P$. putida GG04 has a preference for NADPH. The accumulation of AMDNT and DAMNT was effectively prevented in the presence of guaiacol and catechol. A $89 \%$ reduction of AMDNT and a $80 \%$ of DAMNT was achieved in P. putida GG04 cultures, while in Bacillus sp. SF, 91\% and $70 \%$ reduction was achieved. This demonstrates that biodegradation of TNT in the presence of humic material is effective in immobilizing TNT metabolites. Addition of acetonitrile (1:4) to TNT and to its biodegradation products with sequential freezing of the samples at $-20{ }^{\circ} \mathrm{C}$ was effective in concentrating and enhancing detection signals to identify TNT contaminates sites.
\end{abstract}

Key words: 2,4,6-trinitrotoluene (TNT); explosive; biotransformation; immobilization; humic monomers

\section{НОВ И ПРИЈАТЕЛСКИ ЗА ОКОЛИНАТА ЕКСПЛОЗИВ НА БАЗА НА 2,4,6-ТРИНИТРОТОЛУЕН (ТНТ)}

\footnotetext{
Развиена е нова технологија на биопречистување. Оваа технологија вклучува внесување на нови изолати на Pseudomonas putida GG04 и Bacillus sp. SF во експлозиви за да се зголеми биодеградацијата на остатоците од тринитротолуен (TNT) и експлозивите кои не експлодирале поради технички проблеми. Внесувањето на овие микроорганизми во експлозивот не влијае врз квалитетот на експлозивот во поглед на брзината на детонација додека целосна деградација на TNT по негово пренесување во течна средина е забележано по 4 дена. Внесените микроорганизми го редуцираат последователно TNT, што води до создавање на хидроксиламинодинитротолуени (HADNT), 4-амино-2,6-динитротолуени, 2-амино-4,6-динитротолуени, различни азокси-соединенија, 2,6-диаминонитротолуени и 2,4-диаминонитротолуени. Аминонитротолуените (AMDNT) и диаминонитротолуените (DAMNT) ги сочинуваа доминантните метаболити кои постојано растеа достигнувајќи $41 \mu \mathrm{M}$ и $63 \mu \mathrm{M}$ во културите на P. putida GG04 и $73 \mu \mathrm{M}$ и $109 \mu \mathrm{M}$ во културите на Bacillus SF. Иако и двата микроорганизма за трансформација на TNT користат ензими чиј кофактор e NAD(P)H, P. putida GG04 го преферира коензимот NADPH. Присуството на гвајакол и катехол води до запирање на создавањето на AMDNT и DAMNT. Cо културата на P. putida GG04 се постигнува редукција од $89 \%$ на AMDNT и 80 \% на DAMNT, додека со Bacillus sp. SF се постигнува редукција од $91 \%$ и $70 \%$. Ова покажува дека биодеградацијата на TNT во присуство на хумидни материи е корисна за имобилизацијата на метаболитите на TNT. Додавањето на ацетонитрил (1:4) кон TNT и кон него-
} 
вите продукти на биодеградација со последователно замрзнување на примероците на $-20{ }^{\circ} \mathrm{C}$ се покажа како ефикасна постапка за концентрирање и зголемување на сигналите за детекција со кои се идентификуваат контаминираните делови со TNT.

Клучни зборови: 2,4,6-тринитротолуен (TNT); експлозив; биотрансформација; имобилизација; хумидни мономери

\section{INTRODUCTION}

Naturally occurring nitroaromatic compounds are rare in nature; however, these compounds are produced extensively for application in the explosive, dye, polymer, pesticide and pharmaceutical industries [1]. Among these compounds, TNT is perhaps one of the most widely produced and used nitroaromatic compound. TNT is an explosive which has dominated the military production industry since 1902 [2]. Persistence of TNT is not the only major concern - the electrophillic nature of its nitro groups yields to prompt oxidation of biological molecules [3]. Occupational exposure to TNT results in pathological effects ranging from liver damage, cyanosis, sneezing, cough, sore throat, peripheral neuritis, muscular pain, kidney damage, cataracts, sensitization dermatitis, leukocytosis or leukopenia and aplastic anemia [4]. These adverse effects make the development of new methods for avoiding human exposure a necessity.

Although incineration is the most widely used remediation technology, there is great interest in developing biologically-based technologies which are environmentally friendly and cost effective. However, TNT biodegradation studies up to now have resulted predominantly in biotransformation leading to the accumulation of AMDNT, DAMNT and azoxy compounds [5, 7]. Interestingly, some studies have shown the possibility of immobilizing TNT and its metabolites onto complex soil organic matter during anaerobic TNT degradation $[8,9]$. Coupling of TNT metabolites during TNT biodegradation under aerobic conditions has been shown to be effective, resulting in reduced toxicity $[10,11]$.

Current biological treatment technologies have focused mainly on heavily TNT contaminated sites (production and storage sites). Occupational health risks arising from residues after incomplete detonation of the explosive in the mining and construction sites, or explosives which fail to detonate due to technical failure, have been overlooked. For the first time, the current work attempts to address the destruction of these residual explosives. This is achieved by incorporating microorganisms or their enzyme systems into the explosives formulation. Since biodegradation studies have resulted predominantly in biotransformation, screening for more efficient biodegraders and immobilization of TNT metabolites onto humic monomers are subjects of investigation in this work.

\section{MATERIALS AND METHODS}

\section{Chemicals}

All chemicals used were of analytical grade; 2,4,6-trinitrotoluene (TNT); 2,6-dinitrotoluene and p-nitrotoluene were supplied by a local explosives producer, while 2,4-dinitrotoluene; 2,4-diamino-6nitrotoluene; 2,6-diamino-4-nitrotoluene; 2,2,6,6tetraazoxynitrotoluene; 4-amino-2,6-dinitrotoluene; 2-amino-4,6-dinitrotoluene; 2,6-dinitrotoluene and 2,4-dinitrotoluene were purchased from Accustandards Inc. (New Haven, USA). Contaminated soils and wastewater samples for isolation of microorganisms were also provided by the local explosives producer and stored at $4{ }^{\circ} \mathrm{C}$. All other chemicals were obtained from Sigma-Aldrich and Merck.

\section{Isolation of microorganisms}

TNT contaminated soil and wastewater samples were used as source for the isolation of microorganisms. The enrichment procedure and the detection of TNT removal activity was as described by Gunnison et al. [13]. Pure isolated microorganisms were sent for identification to the German Collection of Microorganisms and Cell Cultures (DSMZ), Germany. In addition, TNT degradation capability of the thermoalkalophilic Bacillus $s p$. SF strain isolated previously from wastewater [12] was investigated.

\section{Liquid cultures}

A medium containing $\left(\mathrm{g}^{-1}\right) 10 \mathrm{~g}$ glucose, $6 \mathrm{~g}$ yeast extract, $5 \mathrm{~g}\left(\mathrm{NH}_{4}\right)_{2} \mathrm{SO}_{4}$ was autoclaved at 121 ${ }^{\circ} \mathrm{C}$ for $15 \mathrm{~min}$, cooled and then supplemented with 
$100 \mathrm{ml}$ sterile basal salt medium. The salt medium contained $\left(\mathrm{g} \mathrm{l}^{-1}\right) \mathrm{K}_{2} \mathrm{HPO}_{4} \quad 0.1,(\mathrm{NH} 4)_{2} \mathrm{SO}_{4} \quad 0.4$, $\mathrm{MgSO}_{4} 7 \mathrm{H}_{2} \mathrm{O} 0.05, \mathrm{KCl} 0.2, \mathrm{CaCl}_{2} 2 \mathrm{H}_{2} \mathrm{O} 0.005$, $\mathrm{FeCl}_{2} \cdot \mathrm{H}_{2} \mathrm{O} 0.005$. TNT solution was prepared by suspending $50 \mathrm{~g}$ TNT in $500 \mathrm{ml}$ deionized water and heating it at $85{ }^{\circ} \mathrm{C}$ for 20 minutes with intermittent stirring. The solution was allowed to cool at room temperature and then filtered to remove undissolved TNT. The culture medium $(25 \mathrm{ml})$, dispensed into a $250 \mathrm{ml}$ buffered flask, was then supplemented with $65 \mathrm{ml}$ TNT solution $(190 \mathrm{mg}$ TNT $1^{-1}$ ). Each flask was then inoculated with $10 \mathrm{ml}$ bacterial culture in its exponential phase (approximately 3.2 absorbance units at $600 \mathrm{~nm}$ ). The inoculated flasks (100ml working volume) were incubated at $30{ }^{\circ} \mathrm{C}$ and at $150 \mathrm{rpm}$. Sampling was done periodically by withdrawing $4 \mathrm{ml}$ which were then centrifuged at $10000 \mathrm{rpm}$. Apart from using the clear supernatant directly for TLC and HPLC analysis, acetonitrile (99\%) in the ratio of $1: 4$ (acetonitrile to sample) was added to the clear supernatant, thoroughly mixed and the mixture frozen at $-20{ }^{\circ} \mathrm{C}$ over night. The resulting organic top phase was then used for TLC and HPLC analysis.

\section{Identification of enzymes involved in initial TNT degradation}

Cells of P. putida and of Bacillus sp. SF harvested from a $2-\mathrm{L}$ culture medium in their late exponential phase (approximately 3.2 absorbance units at $600 \mathrm{~nm}$ ) were washed twice with $50 \mathrm{mM}$ phosphate buffer ( $\mathrm{pH} 7.0)$ and re-suspended in 100 $\mathrm{ml}$ of the same buffer. The suspended cells were cooled on ice and broken with ultrasonic pulses at 2 min intervals (Model Bandelin Sonorex Super RK102H, Berlin, Germany). Cell breakage was monitored microscopically. Cell debris was removed by centrifugation at $20,000 \mathrm{rpm}$ for $20 \mathrm{~min}$, at $4{ }^{\circ} \mathrm{C}$. The extracellular fluid, the broken cells and the intracellular supernatant were then separately incubated with TNT in the absence or presence of cofactors (NADPH, NADH and ATP) for 1h. The reaction mixture contained $150 \mu \mathrm{l}$ of the individually separated fraction, $800 \mu 150 \mathrm{mM}$ phosphate buffer at $\mathrm{pH} 7.0$ containing $200 \mu \mathrm{M}$ TNT and $1.5 \mathrm{mM}$ cofactor concentration. A control was prepared with denatured fractions (boiled at $100^{\circ} \mathrm{C}$ for 10 minutes) and TNT transformation was also monitored as described below.

\section{Immobilization of TNT metabolites on humic monomers during TNT degradation}

P. putida GG04 and Bacillus sp. SF cultures in the mid exponential phase were inoculated with $220 \mu \mathrm{M}$ TNT and then supplemented with $800 \mu \mathrm{M}$ of the respective humic monomers (guaiacol, ferulic acid and catechol). Three controls were prepared. One control flask was supplemented with TNT only while another was also supplemented with the respective humic monomers in the absence of TNT and the third was boiled at $100{ }^{\circ} \mathrm{C}$ for $20 \mathrm{~min}$ to inactivate the bacteria and their enzymes before supplementing it with TNT only. The decrease or reduction in the formation of major TNT metabolites in cultures was recognized as the effect caused by the humic monomers. This was justified by comparing cultures with and without humic monomers.

\section{Monitoring TNT degradation}

During incubation periods residual TNT and TNT degradation products were monitored using different approaches as described below.

\section{Thin layer chromatography (TLC) analysis of metabolites}

Samples were spotted on silica gel 60 plates with fluorescent background ( $\mathrm{J} \mathrm{T}$. Backer Inc, Phillipsburg, NJ, USA), and developed in benzene: hexane (3:1) as mobile phase. For identification of the metabolites, developed plates were observed under $\mathrm{UV}$ at $254 \mathrm{~nm}$. The plates were further sprayed with $10 \%$ tetramethylammonium hydroxide [14] and immediately dried. This allowed the differentiation of the metabolites based on color as well as on Rf-values. The metabolites were identified by comparing $\mathrm{Rf}$ values and color to authentic standards. Detection of TNT degradation products with amino groups was done by immersing developed TLC plates in a solution of $\mathrm{NaNO}_{2}(0.1 \%$ $\mathrm{wt} / \mathrm{vol}$ ) in a $1 \mathrm{~N} \mathrm{HCl}$ for 1 to 2 minutes enough to make the plates wet. Afterwards the plates were dried. The plates were then further immersed in N1-naphthylethylenediamine $\mathrm{HCl}(0.04 \% \mathrm{wt} / \mathrm{vol})$ solution [15] for 2 minutes and allowed to stand for another 3 minutes before drying. Colors resulting from this reaction were compared with colors from the authentic standards. 


\section{HPLC analysis of TNT and its degradation products}

For detection and confirmation of the products of TNT and its metabolites already identified by TLC, HPLC analysis was used. The analysis was performed by HPLC system from Dionex with a P580 pump, an ASI-100 autosampler and a PDA100 photodiode array detector (UV $220 \mathrm{~nm}$ ). Identification and quantitative determination of TNT and its transformation products was done by reversed phase HPLC, on a Discovery HS C18 column $(5 \mu \mathrm{m} ; 25 \mathrm{~cm} \times 4.6 \mathrm{~mm}$, Supelco, Bellefonte, USA.) using 50/50 methanol: deionized water as solvent at a flow rate of $1 \mathrm{ml} \mathrm{min}^{-1}$ and at an oven temperature of $40^{\circ} \mathrm{C}$.

\section{Preparation of microorganisms for incorporation into explosives}

\author{
Preparation of Bacillus sp. $S F$ \\ for incorporation into explosives
}

A spoluration medium for Bacillus sp. SF containing (per liter) $8 \mathrm{~g}$ bacterial nutrient broth, 1 $\mathrm{g} \mathrm{KCl}, 0.25 \mathrm{~g} \mathrm{MgSO}_{4}$ and $0.5 \mathrm{ml} \mathrm{NaOH}(1 \mathrm{M})$ was prepared and autoclaved at $121^{\circ} \mathrm{C}$ for 15 minutes. The medium was left to cool down to $50^{\circ} \mathrm{C}$ before supplementing it with $1 \mathrm{ml}$ of the medium containing $\mathrm{Ca}\left(\mathrm{NO}_{3}\right)_{2} 4 \mathrm{H}_{2} \mathrm{O}(1 \mathrm{M}) ; \mathrm{MnCl}(0.01 \mathrm{M})$ and 1 $\mathrm{ml} \mathrm{FeSO}$ (1 mM) [16]. The medium was inoculated by aseptically transferring the microorganisms from an agar plate into a 1 liter Erlenmeyer flask containing $500 \mathrm{ml}$ medium, and it was incubated at $40{ }^{\circ} \mathrm{C}$ at $150 \mathrm{rpm}$ for 2 days to allow the formation of high biomass. The cultures were then supplemented with $50 \mathrm{~g}$ wood flour to enable the organism to adsorb on to the flour and further incubated while monitoring spore formation. Spore formation was monitored microscopically in the following way. A drop from the culture was mixed with malachite green on a glass slide and fixed by gently heating for 2 to $3 \mathrm{~min}$. The fixed slide was then washed with distilled water and further counter stained with safranin for one minute. The spores stained green while the vegetative cells stained red. Finally the cultures were harvested by carefully decanting excess medium. The remaining filter cake was transferred into 1 liter plastic bottles and frozen at $-20{ }^{\circ} \mathrm{C}$.

\section{Preparation of P. putida $G G 04$ \\ for incorporation into explosives}

For incorporation of $P$. putida GG04 into the explosive, different cryo-protective media were compared. The screened cryoprotectants were milk, honey, raffinose, Na-glutamate, and trehalose [17]. Preliminary screening in cryovials showed $5 \%$ raffinose is the best protective media as evidenced by the viability test of $49 \%$ and was therefore chosen for incorporation. Pseudomonas putida GG04 culture $(500 \mathrm{ml})$ was grown in the medium described before, up to mid-exponential phase (approximately 1.2 absorbance units monitored at $600 \mathrm{~nm}$ ). Two aliquots of $500 \mathrm{ml}$ culture were then transferred into a 21 Erlenmeyer flask containing $50 \mathrm{~g}$ sterile wood flour to enable the organism to adsorb on the wood flour. This mixture was further incubated and later harvested in the late exponential phase by filtering excess water through a $0.45 \mu \mathrm{m}$ filter membrane under sterile conditions. The filter cake (wood flour and microorganisms) was then packed into 11 plastic bottles which were supplemented with $200 \mathrm{ml} 5 \%$ raffinose solution as a protective medium and frozen at $-20^{\circ} \mathrm{C}$.

For the lyophilization and incorporation of the filter cake of both cultures into the explosive, frozen samples were freeze dried using the Labconco Freeze Dry System / FreeZone C 4.5 Liter Benchtop Model 77500 (Vienna, Austria). The freeze drier was operated at a temperature of -48 ${ }^{\circ} \mathrm{C}$ and at a vacuum pressure of $3 \times 10^{-4}$ mbar. The freeze dried filter cakes of $P$. putida GG04 and of Bacillus sp. SF were mixed and then incorporated into a TNT based explosive by the local explosives producer. The quality of the explosive was assessed by measuring the detonation velocity of the explosive.

\section{Recovery of microorganisms from detonation residues and explosive formulation}

To investigate if $P$. putida and B. subtilis were not inhibited after incorporation into the explosive formulation, $3 \mathrm{~g}$ of the TNT based explosive was inoculated in $200 \mathrm{ml}$ culture medium containing $200 \mu \mathrm{M}$ TNT solution (final concentration) in 1-1 Erlenmeyer flasks and incubated under similar conditions described before. The degradation process was monitored by TLC and HPLC. Agar plates overlaid with TNT crystal as in the isolation procedure were also inoculated with the explosive 
formulation containing microorganism. The agar plates were scored for growth and no growth. Long term survival of the microorganism was monitored over a period of 3 years by inoculating $1 \mathrm{~g}$ of the ammonium nitrate explosive containing microorganism onto agar plates and then scoring the colony forming units.

\section{RESULTS AND DISCUSSION}

\section{TNT degradation}

Microbial TNT degradation was detected on plates inoculated with enriched TNT contaminated soil samples. The activity was observed as the disappearance of TNT crystals, the formation of dark red colonies and also some watery transparent spots on agar plates. A bacterial strain (GG05) isolated from the watery transparent spots was identified as Bacillus cereus while another strain (GG04) isolated from the deep red colored colonies was identified as $P$. putida. The ability of the microorganisms to degrade TNT crystals overlaid on agar plates shows overwhelming tolerance of high TNT concentrations, remarkable ability and suitability for in situ degradation of TNT.

TNT degradation profiles in liquid cultures varied from one strain to the other as shown in
Fig.1. TNT degradation by $P$. putida GG04 started immediately after addition of the inoculum in liquid cultures (Scheme 1) and the culture turned to a deep red color. The highest degradation rate of 1 $\mu \mathrm{M}$ TNT per minute was achieved during the period between $2-8 \mathrm{~h}$ of incubation and thereafter the rate drastically declined to $0.1 \mu \mathrm{M}$ per minute. The decrease in TNT degradation may be attributed to either inhibition of the organism by TNT metabolites, or formation of slimlike material excreted by the organism (an attribute of the genus) and accumulating on the walls. Therefore the slim material complexes the organism and some TNT metabolites.

$P$. putida GG04 required $24 \mathrm{~h}$ to completely degrade $220 \mu \mathrm{M}$ TNT (Fig. 1), while B. cereus GG05 achieved only $68 \%$ TNT degradation in the same time. In contrast, the alkalothermophilic $B a$ cillus sp. SF completely degraded this amount of TNT within $22 \mathrm{~h}$ and thus was chosen for further studies as representative of the Bacillus genus. In previous studies, Kalafut et al. [18], observed different ability to transform TNT by Pseudomonas aeruginosa, Bacillus sp and a Staphylococcus sp. . Generally, the TNT degradation efficiency observed in this study is consistent with other studies where similar organisms have been used $[19,20]$.

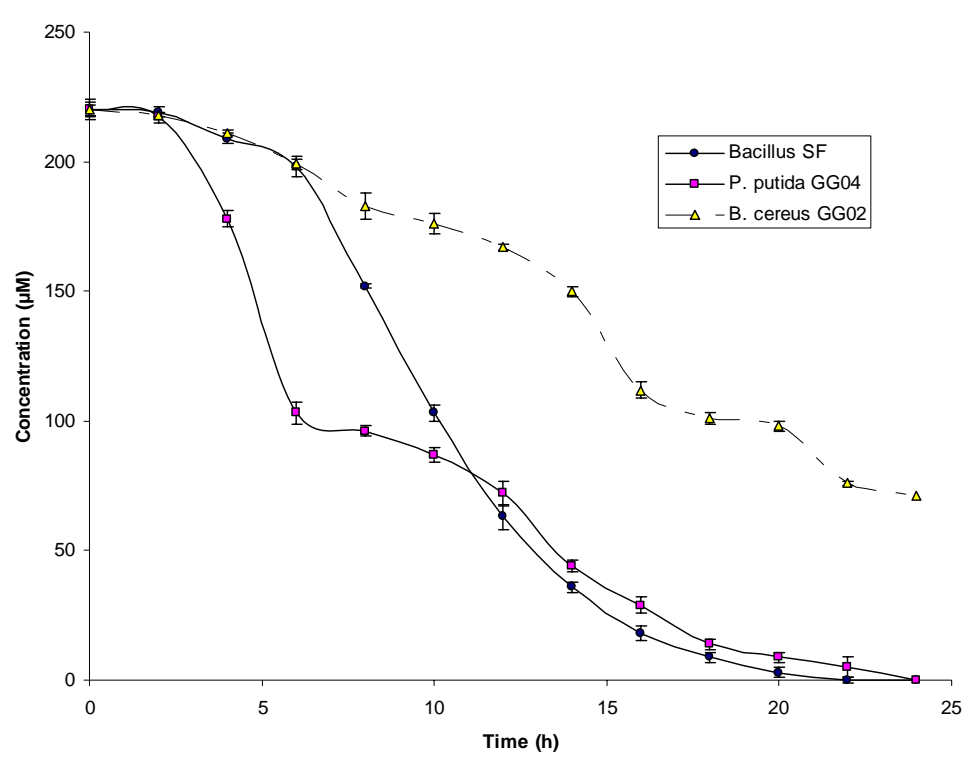

Fig. 1. Biodegradation of TNT by $P$ putida GG04, B. cereus GG02 and Bacillus SF. 


\section{TNT biodegradation metabolites}

A total of 8 different TNT metabolites were identified during TNT degradation by TLC and confirmed by HPLC (Table 1 and Scheme 1). Hydroxylaminodinitrotoluenes (2-HADNT and 4HADNT) were the first detectable metabolites observed after $10 \mathrm{~min}$ of incubation in P. putida GG04 cultures (Scheme 1). In Bacillus sp. SF the products detected during the first 10 minutes were AMDNT (2-AMDNT and 4-AMDNT) and azoxytetranitrotoluene compounds (Scheme 1). Later on DAMNT (2,6-diamino-4-nitrotoluene and 2,4-diamino-6-nitrotoluene) and other azoxytetranitrotoluenes were detected after $4 \mathrm{~h}$ of incubation on TLC for Bacillus SF and by HPLC for P. putida GG04. Although AMDNT were the first metabolites to accumulate, after $8 \mathrm{~h}$ of incubation the concentration of DAMNT was higher than that of ADMNT in both cultures (Fig. 2). Further, an unidentified, highly hydrophilic, dark red metabolite which could not be extracted using most of the organic solvents like methylchloride, chloroform, ethylacetate or hexane appeared during the exponential phase and persisted during the whole incubation period in P. putida GG04 cultures. The metabolite could only be recovered by lowering $\mathrm{pH}$ below 2.5 and formed aggregates which precipitated at the bottom of the flask. The properties of the red metabolite in P. putida GG04 cultures are consistent with data reported by previous researchers for TNT-Meiseinheimer complexes [21, 22]. In addition, there were several other products detected in both cultures which were not positively identified and many more products were detected after prolonged incubation times of up to $48 \mathrm{~h}$ in both cultures (Scheme 1). Of all the products identified, AMDNT and DAMNT were the predominant metabolites, which steadily increased achieving $41 \mu \mathrm{M}$ and $63 \mu \mathrm{M}$ in P. putida GG04 cultures respectively and $73 \mu \mathrm{M}$ and $109 \mu \mathrm{M}$ in Bacillus sp. SF cultures respectively (Fig. 2). As evidenced by the TLC profiles, P. putida GG04 and Bacillus sp. SF use different pathways during TNT biodegradation. Surprisingly the products in both cultures are almost similar after prolonged incubation, that is after $48 \mathrm{~h}$ of incubation (Scheme 1)

\section{Identification of TNT degrading enzymes}

To identify the enzymes involved in TNT degradation, the extracellular fractions, the cell debris and the intracellular fractions were incubated with TNT in the presence and absence of cofactors. TNT degradation activity was detected in intracellular fractions for both P. putida GG04 and Bacillus sp. SF in the presence of NADPH and NADH (Fig 3). In particular, P. putida GG04 transformed $171 \mu \mathrm{M}$ TNT in the presence of $\mathrm{NADPH}$ and $123 \mu \mathrm{M}$ in the presence of NADH. However, the amount of TNT transformed by $B a$ cillus sp. SF intracellular fractions in the presence of NADPH and NADH was almost the same. In both cases nitroreductases have been shown to be the main enzymes involved in the initial TNT biodegradation, which is in agreement with previous results [5]. The preferred reduction of TNT is attributed to the strong electron withdrawing properties of the nitro group which confers a high electron deficiency on the TNT molecule [23].

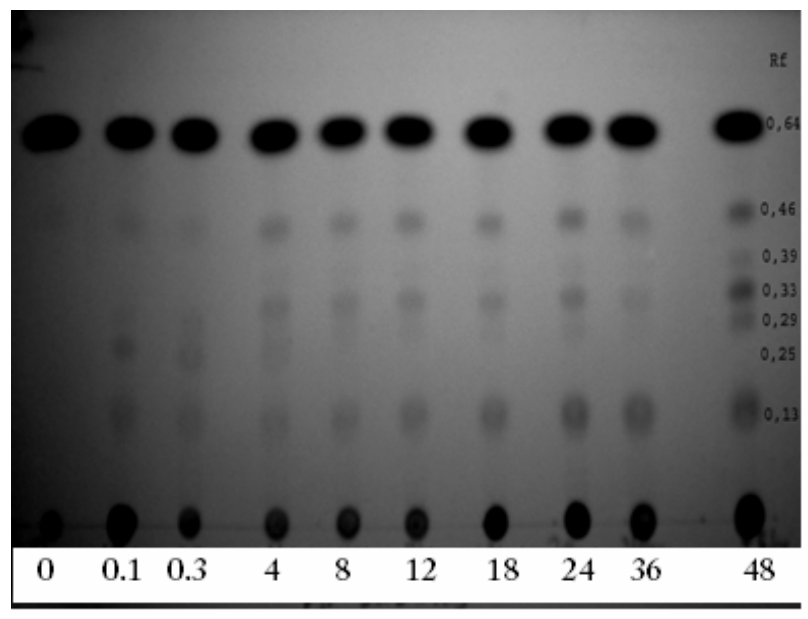

Bacillus SF

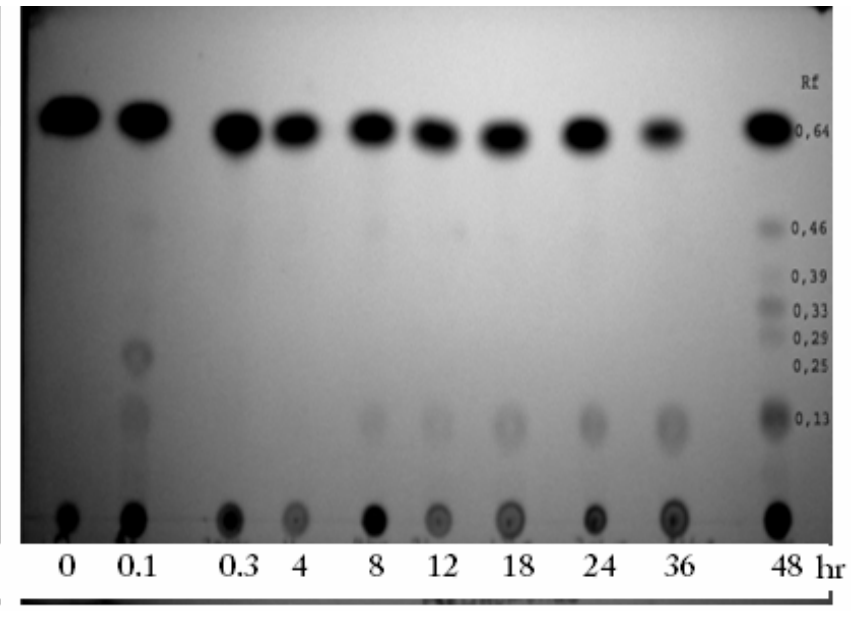

P. putida GG04

Scheme 1. TLC monitoring of TNT degradation products during incubation with Bacillus sp. SF and P. putida GG04. 
Table 1

TLC-Identification of TNT metabolites in P. putida GG04 and Bacillus sp. SF culture samples

\begin{tabular}{cclll}
\hline \hline P. putida GG04 & Bacillus SF & & Product identification \\
\hline Rf values & Rf values & $\begin{array}{l}\text { Treatment with } \\
10 \% \text { TMAH* }^{*}\end{array}$ & $\begin{array}{l}\text { Treatment with } \\
\mathrm{NaNO}_{2} / \mathrm{NED}^{*}\end{array}$ \\
\hline 0 & 0 & red & red-violet & 2,4-DANT; 2,6-DANT \\
0.45 & - & & brown & 4-HADNT \\
0.56 & - & & red-violet & 2-HADNT \\
0.13 & 0.13 & yellow & & $?$ \\
0.23 & - & & & $?$ \\
0.25 & 0.25 & & Azoxy-compound \\
0.29 & 0.29 & red-violet & Azoxy-compound \\
0.33 & 0.32 & intense red-violet & & Azox- compound \\
0.39 & 0.39 & violet & 2,2,6,6-tetraazoxytetranitrotoluene \\
0.46 & 0.46 & brown -violet & & TNT \\
0.64 & 0.64 & brown & & \\
\hline \hline
\end{tabular}

*TMAH - tetramethylammonium hydroxide

*NED - N-1-naphthylethylenediamine

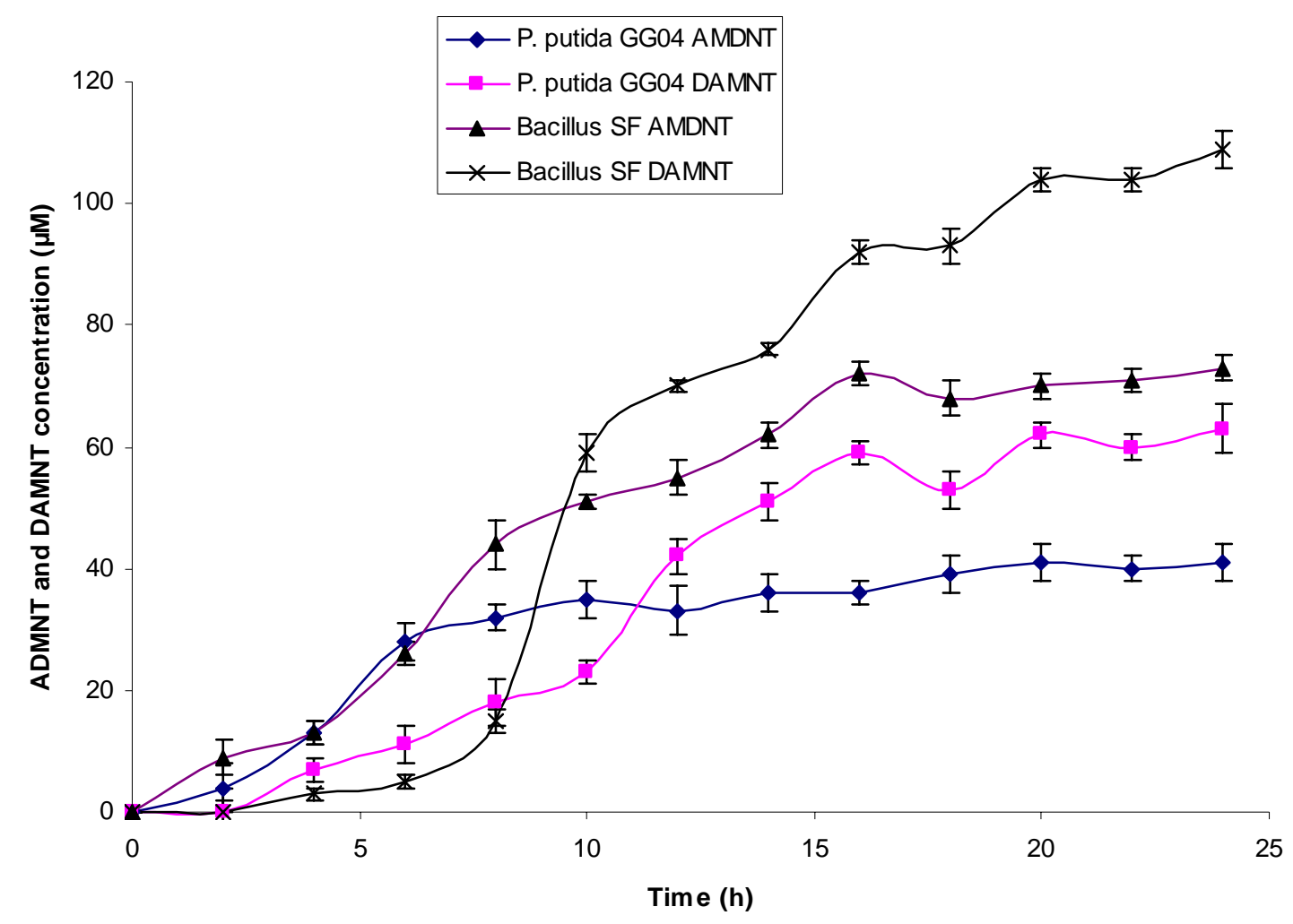

Fig 2. Formation of ADMNT and DAMNT during TNT degradation by P. putida GG04 and Bacillus sp. SF 


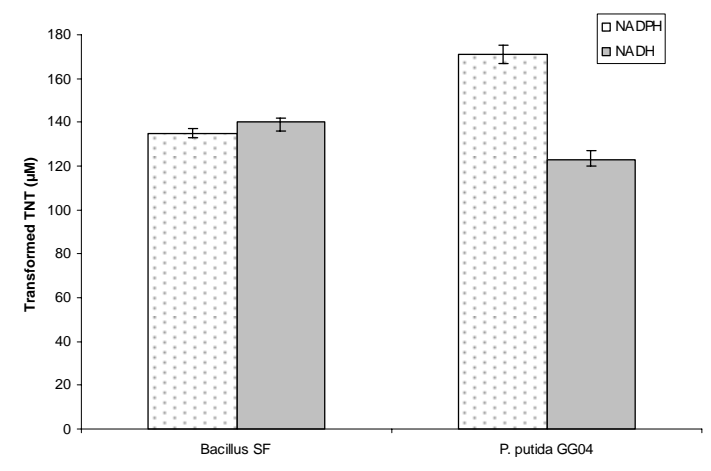

Fig. 3. TNT degradation by intracellular fractions of $P$. putida GG04 and Bacillus SF in the presence of NAD(P)H. There was no TNT biotransformation in the absence of these cofactors.

\section{Immobilization of TNT metabolites onto lignin monomers}

Since AMDNT and DAMNT constituted the major TNT metabolites which persisted during the incubation period, incorporation of humic monomers (catechol, ferulic and guaiacol) was investigated (Fig. 4) to prevent their formation. In the control experiments catechol and guaiacol were evidently transformed, forming a dense precipitate at the bottom and the walls of the flask. However in the control supplemented with ferulic acid no significant transformation was observed. Cultures supplemented with guaiacol were more efficient in preventing the formation of AMDNT and DAMNT (Figs. 4 and 5). An $89 \%$ and $80 \%$ reduction in the formation of AMDNT and DAMNT was achieved, respectively, in P. putida GG04 cultures (Fig. 4).

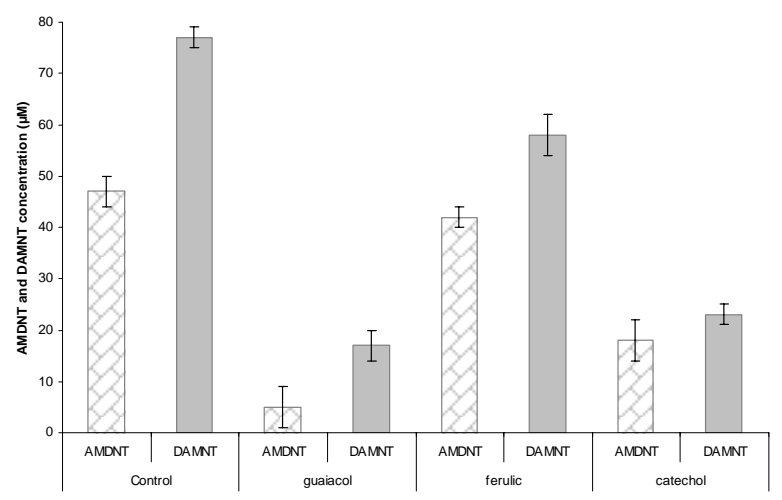

Fig. 4. Effect of incorporating humic monomers (guaiacol, ferulic acid and catechol) during TNT degradation process on the formation of AMDNT and DAMNT in $P$. putida GG04 cultures
Similarly, a $91 \%$ and $70 \%$ reduction in AMDNT and DAMNT was achieved, respectively, in Bacillus sp. SF cultures (Fig. 5). However both cultures supplemented with ferulic acid did not effectively inhibit the formation of AMDNT and DAMNT (Figa. 4 and 5). P. putida GG04 and Bacillus SF produced phenoloxidases as evidenced by the transformation of both catechol and guaiacol in the control experiments. Using different TNT metabolites, Nyanhongo et al. [10] demonstrated complete immobilization of HADNT in the presence of different humic monomers tested in the presence of fungal laccases. Therefore radicals generated by phenoloxidase from catechol and guaiacol may have reacted with HADNT thereby reducing the formation of AMDNT and DAMNT. The different humic monomers have a different coupling capability, as evidenced by ferulic acid. In similar previous studies a total of $71 \%$ TNT was immobilized with catechol as co-substrate while only 25 was immobilized with humic acid as co-substrate [24]. Further, Achtnich et al. [25] and Thorn et al. [26] also provided evidence for different binding capacity of TNT metabolites by different humic fractions.

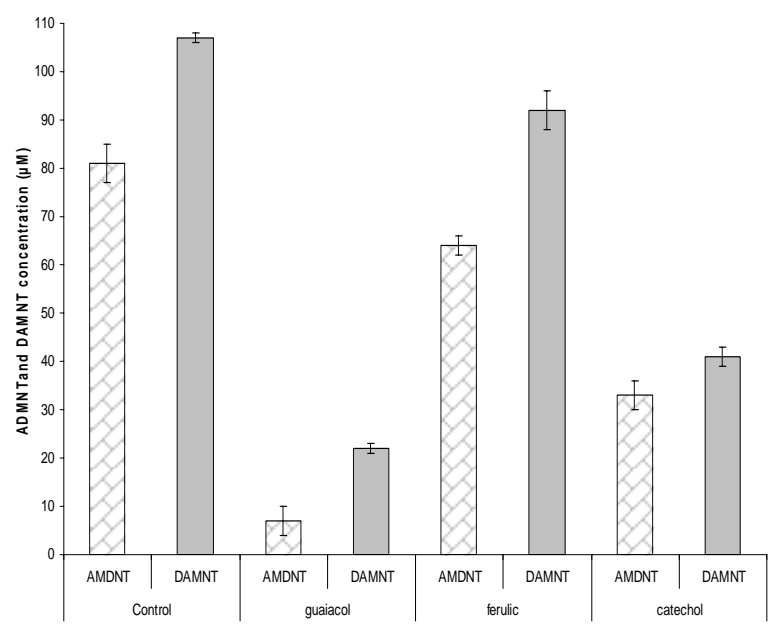

Fig. 5. Effect of incorporating humic monomers (guaiacol, ferulic acid and catechol) during TNT degradation process on the formation of AMDNT and DAMNT in Bacillus sp. SF cultures.

\section{Incorporation of microorganisms into explosives}

The ability of Bacillus sp. SF to produce spores was taken as an advantage for its incorporation into the explosive. Since P. putida GG04 does not produce spores, lyophilization was chosen as the best option. Several potential cryoprotectants 
(milk, honey, Na-glutamate, trehalose, saccharose, lactose meso-inositol and sucrose) were tested and raffinose was observed to offer better protection achieving a survival rate of $49 \%$ after lyophilization. Among the cryoprotectants used, $5 \%$ raffinose gave the highest yield of $39.3 \times 10^{7}$ colony forming units (CFU) $\mathrm{g}^{-1}$ wood flour, while the worst was inositol which gave a yield of only $0.5 \times$ $10^{2} \mathrm{CFU} \mathrm{g}^{-1}$. A large number of different cryoprotectants and bulking agents have been reported for preparing bacterial suspension including saccharose, lactose, trehalose, glycerol, sodium glutamate, meso-inositol, honey, raffinose, sucrose and skimmed milk [17; 27]. These substances generally improve resistance of organism to freezing but their performances depends on the organism. There is therefore an additional need for further studies to find the best protective medium. Again for this study $5 \%$ raffinose was chosen as protective media for the incorporation of P. putida GG04 into the explosive. The wood flour samples coated with microorganisms (Bacillus sp. SF and $P$ putida GG04) were incorporated into the ammonium nitrate based explosive polonit and gelatine donarit explosives.

To confirm that the incorporation of the microorganisms into the explosive formulation did not affect the quality of the explosive, the detonation velocity (which is one of the most important parameter of an explosive) was tested using the ammonium nitrate explosive. This was compared to the reference, which in this case was a normal explosive without microorganisms. The "bioexplosive" (explosive with microorganism) showed better performance with a detonation velocity of $2006 \mathrm{~m} \mathrm{~s}^{-1}$ as compared to the reference with a velocity of $1701 \mathrm{~m} \mathrm{~s}^{-1}$. After incubation of the bioexplosives on agar-plates overlaid with TNT crystals, the crystals disappeared forming a mixture of dark red colonies and watery transparent indicating degradation of TNT. TNT $(200 \mu \mathrm{M})$ was completely degraded within 4 days when $3 \mathrm{~g}$ of explosive formulation containing Bacillus sp. SF and $P$. putida GG04 were added into the liquid cultures.

Long term storage at room temperature of wood flour coated with the Bacillus SF did not affect the organism over the 4 years (Table 2). However, P. putida GG04 cell count decreased with the increase of the storage time such that after 2 years all the cells were inactive (Table 2). Hence, there is still a need to optimize the protec- tive media and lyophilization conditions, in particular those for P. putida.

Table 2

Long term survival of microorganisms in the explosive mixture coated onto wood flour at room temperature

\begin{tabular}{lcccc}
\hline \hline Microorganism & \multicolumn{4}{c}{ Year (CFU/ mg wood flour) } \\
\cline { 2 - 5 } & 0 & 1 & 3 & 4 \\
\hline Bacillus SF & $29 \times 10^{5}$ & $28.9 \times 10^{5}$ & $29 \times 10^{5}$ & $28.5 \times 10^{5}$ \\
P. putida GG04 & $39.9 \times 10^{7}$ & $17.2 \times 10^{7}$ & - & - \\
\hline \hline
\end{tabular}

In this work it was also observed that addition of acetonitrile to samples containing TNT and/or its metabolites (1:4) resulted in most of the products accumulating in the top solvent phase, except the highly polar metabolite, after subsequently freezing at $-20{ }^{\circ} \mathrm{C}$. This approach enhanced the detection signal of the products produced in low concentrations.

TNT degradation remains a complex process due to the unprecedented non enzymatic reactions which reduce the parent compound or the subsequent products. The non enzymatic reactions make it difficult to control directly the reaction process and/or even analyze the degradation process stochoimetrically. Incorporation of $P$. putida GG04 and Bacillus SF into the explosive is a very attractive option, especially for explosives that are used in the mining and construction industry since workers are exposed to great risks. Furthermore, the coupling of TNT metabolites is an interesting approach to avoid leaching and reduce environmental concerns.

Acknowledgements: This work was made possible by the support offered by the Austrian Academic Exchange Service (ÖAD). This work is dedicated to Professor Dr. Herfried Griengl on the occasion of his 70ths birthday in recognition of his contribution to the field of "Applied Biocatalysis".

\section{REFERENCES}

[1] B. van Aken, J. M. Yoon and J. L. Schnoor, Biodegradation of Nitro-Substituted Explosives 2,4,6-Trinitrotoluene, Hexahydro-1,3,5-Trinitro-1,3,5-Triazine, and Octahydro-1,3,5,7-Tetranitro-1,3,5-Tetrazocine by a Phytosymbiotic Methylobacterium sp. Associated with Poplar Tissues (Populus deltoides x nigra DN34), Appl. Environ. Microbiol. 70(1), 508-517 (2004). 
[2] R. D. Harter, The use and importance of nitroaromatic compounds in the chemical industry. In: D. E. Rickert (ed.), Chemical Institute of Toxicology Series. Toxicity of nitroaromatic compounds. Hemisphere Publishing, Washington, D.C, 1985, pp. 1-14.

[3] R. P. Mason, P. D. Josephy, Free radical mechanism of nitroreductase. In: Toxicity of Nitroaromatic Compounds. (Rickert D. E., ed), Hemisphere, New York, 1985, pp.121 -140 .

[4] IARC(International Agency for Research of Cancer), 2,4,6-trinitrotoluene. In. Printing Processes and printing inks, Carbon black and some nitro compounds, Volume 65: IARC Monographs on the evaluation of carcinogens to humans. World Health Organization-International Agency for Reaearch on Cancer, 449-475 (1996).

[5] G. S. Nyanhongo, M. Schroeder, W. Steiner, G. M. Gübitz, Biodegradation of 2,4,6-trinitrotoluene (TNT): An enzymatic perspective, Biocatalysis and Biotransformation, 23 (2), 53-69 (2005).

[7] F. B. Smets, H. Yin, A. Esteve-Nuñez, TNT biotransformation: When chemistry confronts mineralization, Appl Microbiol Biotechnol., 76, 267-277 (2007).

[8] G. Daun, H. Lenke, M. Reuss, H.J. Knackmuss, Biological treatment of TNT-contaminated soil. 1. Anaerobic cometabolic reduction and interaction of TNT and metabolites with soil components, Environ. Sci. Technol., 32, 1956-1963 (1998).

[9] H. Lenke, G. Daun, K. Hund, U. Sieglen, U. Walter, H. J. Knackmuss, Biological treatment of TNT contaminated soil. 2 Biologically induced immobilization of the contaminants and full-scale application. Environ. Sci. Technol. 32, 1964-1971 (1998).

[10] G. S. Nyanhongo, S. Rodriguez Couto, G. M. Guebitz, Coupling of 2,4,6-trinitrotoluene (TNT) metabolites onto humic monomers by a new laccase from Trametes modesta, Chemosphere, 64, 359-370 (2006).

[11] G. S. Nyanhongo, A. Erlacher, M. Schroeder, G. M. Gubitz, Enzymatic immobilization of 2,4,6-trinitrotoluene (TNT) biodegradation products onto model humic substances, Enzyme Microbiol Technol., 39, 1197-1204 (2006).

[12] J. Maier, A. Kandelbauer, A. Erlacher, A. Cavaco-Paulo, G. M. Gübitz, A New Alkali-Thermostable Azoreductase from Bacillus sp. Strain SF, Environ. Microbiol., 70(2), 837-844 (2004).

[13] D. Gunnison, J. C. Pennington, C. B. Price, G. B. Myrick, "Screening test and isolation procedure for TNT-degrading microorganisms", Technical Report IRRP-93-2, U.S. Army Engineer Waterways Experiment Station, Vicksburg, MS. NTIS No. AD A269 124, 1-32 (1993).

[14] N. G. McCormick, F. E. Feeherry, H. S. Levinson, Microbial transformation of 2,4,6-TNT and other nitroaromatic compounds, Appl. Environ. Microbiol., 31, 949958 (1976).
[15] A. M. Tope, K. Jamil, T. R. Baggi, Transformation of 2,4,6-trinitrotoluene (TNT) by immobilized and resting cells of Arthrobacter sp., J. Harzadous Substances Res., 2, 3-9 (1999).

[16] C. Held, A. Kandelbauer, M. Schroeder, A. CavacoPaulo, G. M. Guebitz, Biotransformation of phenolics with laccase containing bacterial spores, Environ. Chem. Lett., 3, 74-77 (2005).

[17] A. M. Malik, Long-term preservation of some Rhodospirillaceae by freeze-drying, J. Microbiol. Methods, 8, 259-271 (1998).

[18] T. Kalafut, M. E. Wales, V. K. Rastogi, R. P. Naumova, S. K. Zaripova, J. R. Wild, Biotransformation patterns of 2,4,6-trinitrotoluene by aerobic bacteria, Curr. Microbiol., 36, 45-54 (1998).

[19] J. W. Pak, K. L. Knoke, D. R. Noguera, B. G. Fox, G. H. Chambliss, Transformation of 2,4,6-trinitrotoluene by purified xenobiotic reductase B from Pseudomonas fluorescens I-C, Appl. Environ. Microbiol., 66, 4742-4750 (2000).

[20] A. Haidour, J. L. Ramos, Identification of products resulting from the biological reduction of 2,4,6-trinitrotoluene; 2,4-dinitrotoluene and 2,6-dinitrotoluene by Pseudomonas sp., Environ. Sci. Technol., 30, 2365-2370 (1996).

[21] C. Vorbeck, H. Lenke, P. Fischer, H. J. Knackmuss, Identification of a hydride-Meisenheimer complex as a metabolite of 2,4,6-trinitrotoluene by a Mycobacterium strain, J. Bacteriol., 176, 932-934 (1994).

[22] C. E. French, S. Nicklin, N. C. Bruce, Aerobic degradation of 2,4,6-trinitrotoluene by Enterobacter cloacae PB2 and by pentaerythritol tetranitrate reductase, Appl. Environ. Microbiol., 64, 2864-2868 (1998).

[23] G. Heiss, H. J. Knackmuss, Bioelimination of trinitroaromatic compounds: Immobilization versus mineralization, Cur. Opinion Microbiol., 5, 282-287 (2002).

[24] S. Thiele, E. Fernandes, and J. M. Bollag, Enzymatic transformation and binding of labelled 2,4,6-trinitrotoluene to humic substances during an anaerobic/aerobic incubation, J. Environ. Qual. 31, 437-444 (2002)

[25] C. Achtnich, E. Fernandes, J. M. Bollag, H. J. Knackmuss, H. Lenke, Covalent binding of reduced metabolites of $\left[{ }^{15} \mathrm{~N} 3\right]$ TNT to soil organic matter during a bioremediation process analyzed by 15NMR spectroscopy, Environ. Sci. Technol., 33, 4448-4456 (1999).

[26] K. A. Thorn, J. C. Pennington, and C. A. Hayes, ${ }^{15} \mathrm{~N}$ NMR Investigation of the reduction and binding of TNT in an aerobic bench scale reactor simulating windrow composting, Environ. Sci. Technol., 36, 3797-3805 (2002).

[27] A.P. Mackenzie, Comparative studies on the freezedrying survival of various bacteria: Gram type, suspending medium and freezing rate, Develop. Biol. Standard, 36, 263-277 (1977). 